\title{
ROLES OF THE COURTS IN NEW ZEALAND IN GIVING EFFECT TO INTERNATIONAL HUMAN RIGHTS - WITH SOME HISTORY
}

\author{
Sir Kenneth Keith*
}

The Right Honourable Sir Kenneth Keith was the fourth speaker at the NZ Institute of International Affairs Seminar. In this paper he describes and reflects upon the role of courts and judges in relation to the advancement of human rights.

In 1968 at this University, over a period of about ten weeks, a series of lectures commemorated the 20th Anniversary of the Universal Declaration of Human Rights. The speakers included a Justice of the Supreme Court of the United States, the Chief Justice of New Zealand, the Attorney-General, the Solicitor-General, two former heads of the legal division of the Department of External Affairs, a formidable critic of the Universal Declaration from the Political Science Department of this University, members of the Law Faculty and our Chairman (just returned from the University of Chicago and then a redoubtable opponent of the proposal for a Bill of Rights). The resulting publication, ${ }^{1}$ including a paper on racial discrimination prepared by a group of honours students, principally concerns the matters I am to address.

\section{FROM 1648 TO 1948 - INTERNATIONAL LAW MAKERS ATTEMPTING TO PROTECT ...}

I plan to make my task more difficult, or apparently so, by going back not just 50 years to the meeting of the United Nations General Assembly in Paris attended by Dr Aikman, but 350 years to 1648, first to make the point that international law makers have been concerned with human rights and fundamental freedoms over a very long

* Judge of the Court of Appeal of New Zealand; Professor Emeritus, Victoria University of Wellington; Associé, Institut de Droit International.

1 K J Keith (ed) Essays on Human Rights (Sweet and Maxwell, Wellington, 1968). 
period. I do that selectively by mentioning briefly the protection which international law has accorded to six groups of people who were perceived to require protection, because they were in real danger, actual or perceived - religious minorities, foreign traders, slaves, aboriginal natives, victims of armed conflict and certain categories of workers. A second purpose of this brief retrospective is to demonstrate the interaction between politicians, judges and scholars, and between international and national actors including many outside the public sector. We should not expect national judges to do it all!

\section{RELIGIOUS MINORITIES AND FOREIGN TRADERS ...}

This year marks the 350th anniversary of the treaties of Westphalia, signed at the end of the Thirty Years War and seen by some scholars as marking the beginning of the modern state. ${ }^{2}$ Among many other things, those treaties, between Sweden and France on the one hand and the Empire on the other, protected the liberties of conscience and religion of various minorities. ${ }^{3}$ Lack of time and my limited knowledge do not allow me to go any further except to note that very soon after the signing of those treaties Sweden and England (or Queen Christina and Oliver the Protector of the Republic) signed a treaty which became applicable to New Zealand about 200 years later and remained in force between Sweden and Norway and New Zealand until 1933. It is the oldest treaty in the recently published New Zealand Consolidated Treaty List. ${ }^{4}$ That treaty protected the rights of aliens. It provided for instance that subjects of either state, being in the other, were to be duly protected and that in the prosecution of their claims in courts of justice, they were to meet with no tedious delays. ${ }^{5}$ - rights which on the English side could be traced back to Magna Carta

\section{SLAVES ...}

My next date is 1772, over 100 years on from Westphalia, when the great English Judge, Lord Mansfield decided a case about James Somersett, a slave, who was seeking his release from that status. Lord Mansfield ordinarily decided cases with great expedition and no obvious strain. On this occasion however, he struggled hard with the parties to get them to compromise. He urged as well the need for parliamentary consideration of the wider set of issues; but the parties were firm to their purpose of obtaining a judgment and after a delay of three terms - in a habeas corpus case where time is usually of the essence - Lord Mansfield was compelled to give judgment which he

2 Consider the reasons given by Clive Parry for beginning the invaluable Consolidated Treaty Series (CTS) with that year, and see eg Gross, "The Peace of Westphalia 1648-1948" (1948) 42 AJIL 20.

31 CTS 119 and 127.

4 Ministry of Foreign Affairs and Trade, Wellington, 1997.

511 April 1654, 3 CTS 257; see similarly art 8 of the treaty of 21 October 1661, 6 CTS 469. 
did, discharging the slave. The judgment is generally remembered not for that procedural and jurisdictional caution but rather for the soaring rhetoric (at least according to some reports - one from only 50 years ago): "the air of England is too pure for a slave to breathe; let the black go free."

Over 50 years later, the 82 year old Lord Stowell, the great Admiralty Judge, in his final year in office gave judgment in another slavery case which he said occasioned him (an abolitionist) great trouble and anxiety. ${ }^{7}$ In a lengthy judgment he decided that an Antiguan slave who had spent a year in England and had returned to Antigua with her mistress had not permanently lost her slave status in Antigua because of her English sojourn. He did not think that the Mansfield judgment required that loss of status. Again he thought that these many questions of very serious import were entitled to the attentive consideration of the legislature, in part so that any change should be at the common expense of both countries and not simply the burden of the particular colony. In that preference for legislative action his judgment is comparable to Lord Mansfield's inclinations. But not in rhetorical reference to principle. Rather he emphasised the facts, including the tolerance by British authorities over the intervening generations of slavery in the colonies. 8

The same judge 10 years earlier had held that the seizure on the high seas of a French slave ship was unlawful. In the course of that judgment he stated two principles of "public law" that he said were generally recognised as fundamental. One was the perfect equality and entire independence of all distinct states. The second was that all nations being equal have an equal right to the uninterrupted use of the unappropriated parts of the ocean for their navigation. Later in the judgment he said that "to press forward to a great principle [of removing the traffic in slaves] by breaking through every other great principle that stands in the way of its establishment; to force the way to the liberation of Africa by tramping on the independence of other states of Europe; in short, to procure an eminent good by means that are unlawful; is as little consonant to private morality as to public justice." 9 Much political activity, international through treaty making and national

6 Somerset $v$ Stewart (1772) Lofft 1, 98 ER 499; The case of James Somersett 20 St Tr 1; Megarry, Miscellany at Law (rev ed 1958) 127-128; Sedley, The Making and Remaking of the British Constitution (1997) 50-51; see also R Q Quentin-Baxter in Keith (ed) n1 above 142-143; and Lester \& Bindman Race and Law (Penquin 1972) 28-34.

7 See his correspondence with Justice Joseph Story, W Story, Life and Letters of Joseph Story (1851) vol $1,552-61$.

8 The Slave, Grace (1827) 2 Hagg 94; 166 ER 179.

9 Le Louis (1817) 2 Dods 210, 243, 256-257; 165 ER 1464. 
through legislation, remained to be taken both to abolish the status and to prohibit the trade. $^{10}$

\section{ABORIGINAL NATIVES ...}

Shortly after Lord Stowell gave his cautious judgments New Zealand legislators and judges began to address the rights of a further group of people at risk, the aboriginal natives of New Zealand following the extension of British rule. In those early days the legislature generally did no more than reserve Maori rights without defining them. ${ }^{11}$ The judicial contributions of the time have already been the subject of extensive analysis. I do not wish to add to it, but to make two points. The first is about the diversity of the sources to which New Zealand judges referred at that time. In the famous case of The Queen $v$ Symonds $^{12}$ Martin CJ and H S Chapman J drew on Chancellor Kent's Commentaries on American Law, Vattel's Droit de Gens, Chief Justice John Marshall's judgments and colonial practice in the Americas and Australia, as well as on Blackstone, Viner and Coke. By placing such emphasis on heritage and continuity they wished to be seen as avoiding, as H S Chapman J put it, what had been referred to by an American Judge as "the vice of judicial legislation". My second point about the old cases is to refer to one aspect of the judgment of Prendergast CJ and Richmond J in Wi Parata $v$ Bishop of Wellington. ${ }^{13}$ After they had made their much criticised statement on "a matter with which we are not directly

10 For part of the law see the Slavery Abolition Act 1833 abolishing slavery in the British Empire, the Slavery Convention of 1926 (60 LNTS 253) and the instruments of 1885, 1890 and 1919 referred to in its preamble, the Supplementary Convention of 1956 (266 UNTS 40), articles 13 and 22 of the 1958 Convention on the High Seas (450 UNTS 82) and articles 99 and 110 of the 1982 United Nations Convention on the Law of the Sea (1982 International Legal Materials 1261); see also the first report of the Law Commission Imperial Legislation in Force in New Zealand (1987 NZLC R1) paras 97-101. For an outstanding history see Hugh Thomas, The Slave Trade : the History of the Atlantic Slave Trade 1440-1870 (1997) especially books 5 and 6.

11 Land Claims Ordinance 1841 s2 (reserving as against the Crown title "the rightful and necessary occupation and use thereof, by the Aboriginal inhabitants ..."), and Fish Protection Act 1877 s8 (Act not affecting the Treaty of Waitangi or any rights of aboriginal nations to any fishery under it). (1847) NZPCC 387n.

13 (1877) 3 NZJur (NS) SC 72 
concerned" to the effect that article 1 of the Treaty must be regarded as a simple nullity, 14 they turned to the substance of article 2 and said that

So far as the proprietary rights of the natives are concerned, the so called treaty merely affirms the rights and obligations which, jure gentium, vested in and devolved upon the Crown under the circumstances of the case.

It is of course true that the court in that case did not enforce any such rights, but it did recognise that native people did have rights under the Law of Nations.

\section{VICTIMS OF ARMED CONFLICT ...}

A fifth group of people in danger who were protected by international law by that time were the victims of armed conflict. The first generally accepted treaty text is the first Geneva Convention of 1864, on the amelioration of the conditions of the wounded in armies in the field, ${ }^{15}$ the second multilateral treaty included in the New Zealand Consolidated Treaty List. That convention was animated, according to its preamble, by a desire to reduce so far as possible the evils of warfare, to suppress unnecessary suffering and to improve the fate of wounded soldiers on the field of battle. Accordingly it protected ambulances, military hospitals, associated staff, local inhabitants who assisted, and the wounded and sick soldiers themselves. A distinctive flag and armband - a red cross on a white ground (the Swiss flag reversed) - was also to be protected. A great body of law has since developed, including a range of methods of implementation. As in other areas of the international protection of human rights, there are dreadful breaches of the law. As well there is a worrying failure by states to use some of those procedures but that failure is to be balanced by developments, for instance in respect of the long established essential role of the International Committee of the Red Cross and the recent establishment or proposed establishment of ad hoc and permanent international criminal courts.

14 The reference is to the Treaty of Waitangi. Another of Lord Stowell's judgments is relevant to that matter of status. At the beginning of the century in a case involving actions by "the Algerines" he had held that although the (north) African States had once been considered merely as pirates when taking ships "they have long acquired the character of established governments, with whom we have regular treaties; acknowledging and confirming to them the relations of legal states." The Helena (1801) 4 C Rob 3, 5-6; 165 ER 515.

15 The protection of course goes back much earlier; see eg Suarez, Disputation XIII : On Charity; part VII what is the proper mode of conducting war? (1621), in Selections from Three Works (published 1944) vol II, 836 . 


\section{AND WORKERS}

By the end of the 19th century another group of people at risk - the sixth and last in my list - were seen to be in need of protection by international law as well as by national legislation. The latter would not be effective without the former. They were workers, especially in dangerous industries. The International Association for Labour Legislation was established in 1900 at a meeting held in Paris. One of its objectives was to further the study of the question of procuring uniformity in the various codes of labour laws. ${ }^{16}$ (Some caution can be seen in the formulation of that objective: those setting up the organisation did not presume that uniformity of national law would be the inevitable result of any particular study.) Two multilateral conventions resulted from that endeavour in 1906 and New Zealand became bound by both of them a few years later. ${ }^{17}$ Both declare the wish of the parties to facilitate the protection of workers by the adoption of common laws. That is to say they had accepted the proposition that progress could better be made by national law if it was supported by international agreement. One of the conventions prohibited night work by women in factories, a treaty from which New Zealand withdrew only in the early 1980s. The other was aimed at "phossy jaw" which resulted from the making of matches from white or yellow phosphorous. The convention forbade the manufacture, import and sale of matches made with white phosphorous. Until the enactment of the Health and Safety and Employment Act in 1992 that treaty was given particular effect in full or in part by New Zealand legislation. ${ }^{18}$ New Zealand remains bound by it.

The protection of workers and the explicit recognition that they were not mere commodities or articles of commerce were taken a further step forward in 1919 with the establishment by the international community of the International Labour Organisation. The preamble to its constitution includes the proposition that the failure of any nation to adopt humane conditions of labour is an obstacle in the way of other nations which desire to impose the conditions in their own workplaces. (The caution of 1900 has lessened if not disappeared.) I note just one of the principles that the treaty makers stated in 1919, since it is relevant to a case I will mention later and since some would be surprised to find it stated so long ago and in the aftermath of the Great War: equal remuneration for work of equal value for men and women.

16 Eg Hon Mr Paul in the Legislative Council 151 NZPD 232-233.

17203 CTS $4,12$.

18

Phosphorous Matches Act 1910, and Factories and Commercial Premises Act 1981 s32 (although note that the latter provisions narrow the scope of the prohibition). 


\section{BUT IN 1945 AND 1948 THE MOVEMENT IS TO UNIVERSAL PROTECTION}

To conclude this part of this paper, I would repeat that the major developments, even the revolutionary developments, in 1945 and 1948 (followed by the careful elaboration of particular human rights texts) are to be seen in the context of those earlier endeavours. They show that it is not extraordinary for the international lawmaker to prepare law which protects the rights of individuals. I would not however wish to diminish the immense importance of the developments after the Second World War in their universalising of human rights and fundamental freedoms and in their general recognition (which for many countries came only belatedly) that sovereignty did not necessarily stand in the way of the examination by the international community of the actions of states taken against their own people. ${ }^{19}$

Michael Ignatieff, a brilliant trans-Atlantic intellectual, provides in his most recent book, The Warrior's Honor : Ethnic War and the Modern Conscience ${ }^{20}$ an excellent summary comment, linking the first part of this paper to its second:

The world is not becoming more chaotic or violent, although our failure to understand and act makes it seem so. Nor has the world become more callous. Weak as the narrative of compassion and moral commitment may be, it is infinitely stronger than it was only fifty years ago. We are scarcely aware of the extent to which our moral imagination has been transformed since 1945 by the growth of a language and practice of moral universalism, expressed above all in a shared human rights culture. Television in its turn makes it harder to sustain indifference or ignorance. Finally, the army of aid workers and activists who mediate between the zones of our world continues to grow in strength and influence. They remain our moral alibi, but they are also the means through which deeper and more permanent commitments can be made in the future. There is nothing in the emergence of this global conscience that gives us reason to be complacent. But there is also nothing that justifies disillusion.

This part of the paper concerns the role of New Zealand courts in giving effect to the universal human rights culture to which Ignatieff refers. Unlike the essays published in 1968, this part does not attempt to survey the substantive areas of law covered by the Universal Declaration and the related instruments. ${ }^{21}$ Rather it identifies and to a limited extent illustrates various ways in which New Zealand courts have or might make use of

19 See eg the NZIIA publication International Implications of Race Relations in New Zealand (1972).

$201998,8$.

21 See also the initial and periodic reports which the New Zealand Government has made to the various treaty bodies established under the Covenants and the Racial Discrimination, Women's Discrimination, Children and Torture Conventions, as well as those to the International Labour Organisation and UNESCO. 
international human rights instruments. ${ }^{22}$ The discussion is largely limited to New Zealand cases, but similar accounts can and have been given of comparable jurisdictions. ${ }^{23}$

\section{TREATIES ARE NOT PART OF THE LAW OF THE LAND}

We begin with the constitutional principle that in general treaties are not part of the law of New Zealand and if rights and duties under that law are to be altered legislation is required. ${ }^{24}$ By contrast customary international law is part of the law. ${ }^{25}$

Accordingly any thorough assessment of the implementation in New Zealand law of human rights treaties must give primary attention to a very diverse body of statute law concerned for instance with slavery, war crimes, piracy and related maritime crimes, crimes against international aviation, narcotics, torture, genocide, labour conditions, discrimination, criminal procedure and privacy as well as with human rights more generally. ${ }^{26}$

Six possible roles for the courts in giving effect to or making use of international human rights texts can be identified. The following brief description will indicate that some are more clearly established than others.

\section{BUT THEY MAY HAVE A CONSTITUTIONAL ROLE}

A treaty might be a source of, or place limits on, the constitutional powers of the state. The issue has arisen in New Zealand courts in relation to three matters : the general law making powers of the New Zealand Parliament before 1947 when earlier limits were removed, the Mandate for Western Samoa, and the Treaty of Waitangi.

22 See the discussions in recent Law Commission publications A New Zealand Guide to International Law and its Sources (NZLC R34 1996) ch3 and The Treaty Making Process : Reform and the Role of Parliament (NZLC R45 1997) paras 37-42 and 87-93; see also Hastings "New Zealand Treaty Practice ..." (1989) 38 ICLQ 668 and "The Application of International Human Rights Law in New Zealand" (1997) 32 Texas ILJ 401.

23 Eg Jennings and Watts Oppenheim's International Law (9th ed 1992) 52-86.

Eg New Zealand Air Line Pilots Association v Attorney-General [1997] 3 NZLR 269.

25 Eg Controller and Auditor General v Davison [1996] 2 NZLR 278.

26 See eg the list of statutes with possible implications for New Zealand treaty obligations included in the Law Commission's Guide, n 20 above, 116-119. The first in the list is the Abolition of the Death Penalty Act 1989 (giving effect to the Second Optional Protocol to the International Covenant on Civil and Political Rights) and the second the Accident Rehabilitation and Compensation Insurance Act 1992 (giving effect to ILO Conventions on workers compensation and saving the effect of the Warsaw Convention on Carriage by Air). 
In 1906 a Supreme Court of four judges answered questions about the applicability of industrial awards to ships registered in New Zealand and Victoria. ${ }^{27}$ There were three variables : the place of registration, the place of domicile of the owner, and whether the ship was trading to and from New Zealand. The legal question began with the power of the New Zealand Parliament under the New Zealand Constitution Act to make laws for the peace, order, and good government of New Zealand. All the judges saw international law, customary rather than treaty, conferring jurisdiction (generally exclusive) on the flag state even in foreign ports as important in determining the scope of that power. Stout CJ used it positively when identifying an increasingly distinct New Zealand personality. "It was not left in the swaddling bands of a precise written Constitution, for the words of the Constitution Act are general." The government of the colony would be imperfect and incomplete and we would not have true responsible government if the legislature of New Zealand could not deal with the persons and property of New Zealanders. Parliament in making this claim to deal with New Zealand ships engaged in New Zealand trade does not invade any Imperial, foreign or other colonial jurisdiction. But New Zealand power did not extend to the Victorian ships and company. In support of that particular result, Chapman and Cooper JJ invoked "a cardinal rule" for the interpretation of a Constitution that it shall not offend against the rules of international law and so clash with and hamper the liberty of action of another colony or state:

It would be contrary to the principles of international law, and contrary to the intention of the Imperial Parliament as expressed in these Constitution Acts [for New Zealand and Australia], to hold that one Parliament had power to enjoin and the other to prohibit the same act ....

In a series of cases in the 1920s and 1930s the authority of Parliament to legislate for the Mandated Territory of Western Samoa was disputed. In a number of judgments the courts based the authority directly on the Mandate, in one case saying that the fullest plenary powers left the League of Nations and were not restricted on their way to New Zealand - as had also been decided in South Africa and was the view of the lawyers in the Colonial Office. ${ }^{28}$

27 Re the Award of the Wellington Cooks and Stewards Union (1906) 26 NZLR 394.

28 See "International Law and New Zealand Municipal Law" in J F Northey (ed) The A G Davis Essays in Law (1965) 130, 144-146, and A Frame Salmond : Southern Jurist (1995) 189-198. 
That apparent departure from the orthodox position that treaties are not part of the law of the land has not been followed in the cases relating to the Treaty of Waitangi. On the constitutional issue I can do no better than quote Lord Cooke of Thorndon: ${ }^{29}$

There are those who contend that the Treaty must be seen as the foundation document of New

Zealand, not only in fact as it undoubtedly was, but in law also: a kind of grundnorm, a

political compact as fundamental for our South Pacific country as was the Magna Carta for

England. The Courts have not yet had to face squarely the profound jurisprudential questions

raised by such contentions; and long may that remain the position.

A similar uncertainty is to be found in respect of the Act of Union between England and Scotland. Scottish litigants, contending that the powers of the Parliament at Westminster are limited by the Act of Union, have argued that legislation relating to matters as diverse as service abroad, the Queen's Title, fisheries and the poll tax was invalid for breach of those treaty limits. The courts have never ruled definitively on the constitutional issue, finding, in effect, various ways to avoid the issue. For instance, in a fisheries case in which European regulations were being challenged as not "for the evident utility" of the subjects of Scotland (a standard in the Act of Union for the making of law for Scotland), Lord Keith expressed the opinion that that question "is not a justiciable issue in this court". ${ }^{30}$

By contrast a much more recent apparent treaty-based set of restraints on the power of the Parliament at Westminster has been successfully invoked in English courts. ${ }^{31}$ They arise from the treaties setting up the European Union. The restraints may include human rights limits. It is interesting that, notwithstanding this precedent, the Bill to give effect to the European Convention on Human Rights does not give it entrenched status, as Lord Cooke points out in his contribution to this seminar.

\section{BE RELEVANT TO DETERMINING THE COMMON LAW}

The cases indicate two developing uses of treaties in the area of common law. Treaties may be directly used even in the absence of any legislation as evidence of customary international law which is part of the common law. One instance is the use by the courts of aspects of the law of treaties (included in New Zealand law) as stated in the

29 Rt Hon Sir Robin Cooke, "A Sketch from the Blue Train Non-Discrimination and Freedom of Expression: The New Zealand Contribution" (1993) 19 Commonwealth L Bull 1782, 1791.

30 Gibson v Lord Advocate 1975 SC 136, 143-144, 1975 SLT 134, 137. For the other cases see 8(2) Halsbury's Laws of England (reissue 4th ed) para 53 and n 15.

$31 R v$ Secretary of State for Transport, ex parte Factortame Ltd (No 2) [1991] 1 AC 603, 658-659, and eg $R v$ Kent Kirk [1984] 3 CMLR 522, 538 (on non-retroactivity). 
Vienna Convention on the Law of Treaties. ${ }^{32}$ Courts considering common law rules about freedom of expression have similarly referred to relevant international human rights instruments. ${ }^{33}$

\section{GIVE CONTENT TO THE WORDS OF A STATUTE}

A prosecution of the leader of the National Socialist Party of New Zealand in 1977 for publishing written matter intending to excite ill-will against Jews raised the issue whether the Jews in New Zealand formed a group with common "ethnic origins" for the purpose of the Race Relations Act 1971. The judgments of the Court of Appeal answering the question yes were based in part on various dictionary meanings, and on the evidence of an expert witness, but also on the international context in which the offence was to be seen, the appropriate approach to the interpretation of a treaty based provision, ${ }^{34}$ the International Convention on the Elimination of all Forms of Racial Discrimination and the drafting history of that Convention. ${ }^{35}$ The same approach was not but could have been adopted in a more recent case relating to the meaning of "slave" in the Crimes Act $1961 .^{36}$

\section{HELP INTERPRET LEGISLATION WHICH IS IN LINE WITH THE TREATY}

In an increasing range of cases New Zealand judges have restated the proposition, found for instance in the maritime case 90 years ago, that legislation should if possible be interpreted consistently with New Zealand's international obligations.

They are sometimes helped in that by the legislation's identifying the relevant convention, as the New Zealand Bill of Rights Act 1990 so plainly does. According to its title expressly it is an Act "to affirm New Zealand's commitment to the International Covenant on Civil and Political Rights". The wording of many of its provisions follows

32 Eg New Zealand Airline Pilots' Assn v Attorney-General [1997] 3 NZLR 268, 289 and the cases referred to there.

33 Eg Television New Zealand Ltd $v$ R [1996] 3 NZLR 393, 396-396 (where the court left open the question whether the power in question was statutory or common law) and Lange $v$ Atkinson and ACP NZ Ltd [1997] 2 NZLR 22, 38-39.

34 Quoting Lord Wilberforce (quoting Lord Macmillan) in James Buchanan \& Co Ltd v Babco Forwarding and Shipping (UK) Ltd [1978] AC 141, 152, a passage which has been used since in New Zealand Maori Council v Attorney-General [1987] 1 NZLR 641, 714; CBI NZ Ltd v Badger Chiyoda [1989] 2 NZLR 669, 682. See also Commissioner of Inland Revenue v United Dominions Trust Ltd [1973] 2 NZLR 555, 558.

35 King Ansell v Police [1979] 2 NZLR 531, especially at 537 and 540-541.

$36 R v$ Decha-Iamsakun [1993] 1 NZLR 141; see the 1926 and 1956 Conventions referred to in $\mathrm{n} 10$ above. 
exactly or is closely related to the text of the Covenant. Accordingly many cases in which the Bill has been invoked refer to the Covenant and to interpretations given to it or to similar provisions in national and international jurisdictions. So the computer data base for Court of Appeal judgments since 1992 has 110 references to the Covenant - although not all would be in Bill of Rights cases. In one of the earliest of those cases both the present President of the Court and his immediate predecessor stress the central importance in the interpretation and application of the Bill of Rights of its international basis and origin. ${ }^{37}$

That decision concerned the rights of drivers suspected of drink driving offences. At the time of this seminar the most recent major discussion of a Bill of Rights provision in its Covenant context concerns the decision that same sex marriages do not fall within the scope of the Marriage Act. ${ }^{38}$ The relevant provisions guaranteed equality before the law and prohibited discrimination (although in somewhat different terms). The various judgments draw on decisions from 12 different national and international jurisdictions, the drafting history of the Covenant, and extensive scholarly writing. The legal profession including the judges and (to anticipate a matter to which I will return) the academics are becoming more familiar with that range of material. I leave it to others to comment on that and related judgments and to balance the opinions of those who say that members of the Court went unnecessarily into some of the matters discussed ${ }^{39}$ with the opinions of those who say that in related areas we have unnecessarily held back. ${ }^{40}$

\section{HELP INTERPRET LEGISLATION WHICH IS DESIGNED TO GIVE GENERAL EFFECT TO THE TREATY (BUT WHICH IS SILENT ON THE PARTICULAR MATTER)}

The NZ Bill of Rights Act does not contain a remedies clause, while the International Covenant on Civil and Political Rights which Parliament affirmed in enacting that measure does require state parties to provide effective remedies by a competent authority. In Baigent's Case ${ }^{41}$ the Court of Appeal decided that a monetary remedy could be available for breaches of a right included in the Bill. The court placed particular

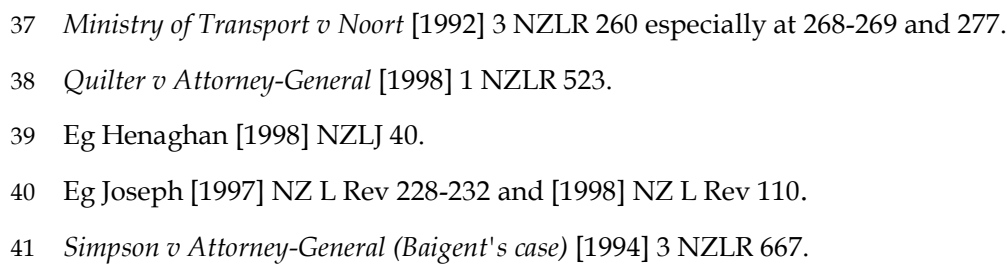


emphasis on the treaty obligation to provide an effective remedy. Reference was made as well to the Human Rights Committee set up under the Covenant: ${ }^{42}$

The Act reflects Covenant rights, and it would be a strange thing if Parliament, which passed [the Bill of Rights Act] one year [after New Zealand acceded to the First Optional Protocol], must be taken as contemplating that New Zealand citizens could go to the [Human Rights Committee] for appropriate redress, but could not obtain it from our own Courts.

In a broad sense members of the court were looking to a purposive interpretation. They might also have been reflecting on the United Kingdom experience of the gap between effective remedies abroad under the European Convention and ineffective ones at home.

A drug sentencing appeal presented a different challenge since the particular statute made no reference to the Single Convention on Narcotic Drugs which New Zealand ratified at about the time it was enacted. For the judge however "the inference that the statute was intended to embody the convention is irresistible." The judge used the presumption of interpretation of compliance with those obligations in resolving a conflict between two different statutory directions about sentencing. Since the Convention called for "adequate punishment" for serious offences "particularly by imprisonment or other penalties of deprivation of liberty" and did not provide for the consideration of age, he considered the youth of the offender should not have been considered as it had been by the sentencing judge. ${ }^{43}$

\section{AND HELP TO INTERPRET AND AFFECT THE OPERATION OF LEGISLATION TO WHICH THE INTERNATIONAL TEXT HAS NO APPARENT DIRECT RELATION}

The lack of direct relationship may be a function of time where the international text is prepared or ratified after the legislation is enacted. ${ }^{44}$ Some might say it may also be a function of subjectmatter since, for instance, those responsible for the preparation and enactment of legislation in one area may be considered not to have in mind treaty provisions operating essentially in a quite different area of administration.

While courts elsewhere have sometimes confined the relevant treaties to legislation which was designed to give effect to the treaty, New Zealand courts in general have not.

42 Above n 41, 703. See also pp 691, 699.

43 Police $v$ Hicks [1974] 1 NZLR 763, 766.

44 See for instance the hesitation in New Zealand Van Lines Ltd v Proceedings Commissioner [1995] 1 NZLR 100, 103, but compare the approach to interpretation adopted at 103-104, and New Zealand Air Line Pilots' Association v Attorney-General [1997] 3 NZLR 269, 289 (referring to the Pitcairn case). 
Indeed the relevant international text may not even be binding on New Zealand, for instance because New Zealand has not accepted it or it is not in treaty form or otherwise binding. The broader approach is supported, first, by the proposition that legislation should if possible be read consistently with New Zealand's international obligations (as already noted the courts impute to Parliament an intention to legislate consistently with those obligations) and, second, by a more integrated view of the law and its various sources.

One case where international material which was not directly binding and applicable but nevertheless did have a real impact concerned the removal allowances and expenses for the family of a married woman school teacher. She was entitled to less than a married man teacher. Cooke J sitting in the Supreme Court in 1977 held that the Minister in fixing "the general conditions governing payment of removal expenses" (under a power conferred on him by regulation) could not discriminate in that way. ${ }^{45} \mathrm{He}$ had four reasons for that conclusion. Coming to the last, "reference to certain international documents, though not essential, is not out of place". He referred to prohibitions on discrimination against women, including in the work place, to be found in the Universal Declaration, the 1967 Declaration on the Elimination of Discrimination against Women, and the Equal Remuneration Convention 1951 (noting that New Zealand was not party to it).

The issue has arisen in recent immigration cases when people subject to deportation have contended that those exercising broad powers are obliged to have regard to treaty provisions about the rights of family members and of children in exercising those powers. ${ }^{46}$ The Court of Appeal has so far not ruled on the matter, in the latest relevant case, noting four factors at least on each of the two sides of the question whether the Ministerial power to revoke a removal order is subject to the international obligations. I mention just one on each side. In favour of a positive answer is the presumption that so far as its wording allows legislation should be read in a way which is consistent with New Zealand's international obligations. On the other side is the consideration that an independent tribunal is expressly required to have regard to the humanitarian considerations required to be considered by the international text while the Minister is not.

As well, the Court of Appeal has yet to consider fully the proposition stated by the High Court of Australia that the ratification of a treaty gives rise to a legitimate

45 Van Gorkom v Attorney-General [1977] 1 NZLR 535, affirmed [1978] 2 NZLR 387.

46 Tavita $v$ Minister of Immigration [1994] 2 NZLR 257, Puli'uvea v Removal Review Authority (1996) 14 FRNZ 322 and Rajan v Minister of Immigration [1996] 3 NZLR 543, 551-552. 
expectation, in the absence of any legislation or executive indication to the contrary, that the executive would act in accordance with the treaty. ${ }^{47}$

Variables relating to the legal texts, judicial attitudes and method, and the wider legal and political culture can be seen at work in the cases. To conclude, I comment briefly on those three matters.

\section{A The legal texts}

The Law Commission, by reference to a wide range of treaties to which New Zealand is party and relevant New Zealand legislation, has highlighted the fact that some treaties are readily capable of direct application in national courts while others call for detailed legislative or other national acts of implementation (sometimes explicitly). ${ }^{48}$ I have one comment on the former category and a question about the latter. The comment on the former is that our legislators should hesitate before thinking that they can improve on the international text if it does have that capability. Attempts to do that have caused unnecessary litigation, costs and distress. The Government should respond positively to the Law Commission's recommendation to that effect. ${ }^{49}$

The question, is to ask whether there may not be value in the New Zealand constitutional system of the distinction drawn elsewhere between self-executing and non self-executing treaties. The refusal of courts in countries in which treaties are said by the constitution to be "part of the law of the land" to give effect to treaties in the latter category can be related to the refusal of Scottish judges to find a justiciable standard in the undertaking in the Act of Union that legislation is not to be "for the evident utility" of the Queen's subjects in Scotland.

On the other hand all legal systems do use broad standards and principles and courts do elaborate, develop and apply them - or see them as relevant to the exercise of power by administrators - at least in some situations. That can be seen for instance in cases about the principle of equality or the prohibition on non-discrimination whether the principle is included in treaties, constitution or statute. ${ }^{50}$

47 Minister of Immigration and Ethnic Affairs v Teoh (1995) 128 ALR 353; for one reference to it in the Court of Appeal see New Zealand Maori Council v Attorney-General [1996] 3 NZLR 140, 184.

48 There are also intermediate categories; see the Guide, n 22 above, ch 2.

49 See recommendation 3 in the Treaty Making Process n 22 above, and compare for instance the drafting of the statutes giving effect to the Hague Conventions on Child Abduction and Intercountry Adoption, Guardianship Amendment Act 1991 (especially in its original form, see Gross v Boda [1995] 1 NZLR 169 and cases preceding it) and the Adoption (Intercountry) Act 1997.

50 Eg Attorney-General of Western Samoa v Saipa'ia Olomalu (1984) 14 VUW L R 275; Le Tagaloa Pita v Attorney-General (WSCA, 18 December 1995); Clarke v Karika [1985] LRC (Const) 732; Quilter v 
But it is nevertheless the case that when Parliament uses general language or confers powers with no explicit limits, problems arise for the judicial role. In some cases as we have seen the international texts will help give content to or place limits on the apparently broad statement. But in other cases Parliament's use of broad wording may be seen as deliberate, especially when it uses more confined language elsewhere in the statute or in related statutes. Again careful attention has to be given to the preparation of such legislation.

\section{B Judicial attitudes and method}

So far as judicial attitudes are concerned H S Chapman J's worry not to be seen to be engaging in "the vice of judicial legislation" can be put against the increasingly explicit recognition by judges in many jurisdictions in the last 30 years or so that they do make law. In my experience that is sometimes unavoidable if only because the law is not clear. The question accordingly may not be whether but when and how. Relevant to the how question is the use made of international law materials, a matter related to my last variable, the wider legal and political culture in which these issues arise. As noted already, more than 150 years ago New Zealand judges in the Symonds case showed a familiarity with a wide range of sources relevant to the rights of natives. My sense is that the judges' focus narrowed from late last century into the middle of this, with only limited exceptions such as Stout CJ (but his professional experience began in the earlier, more expansive, period) and Salmond J (and his experience too differed widely from that of his colleagues). ${ }^{51}$ For instance as recently as 1967 an outstanding judge said, accurately of course but it is the sense that interests me, "It needed no Charter of the United Nations to make [freedom of opinion, including the right to protest against political decisions] acceptable to us". ${ }^{2}$ My sense of changing attitudes is supported by a review of the dates of the cases mentioned earlier in this paper.

That change is to be related to many matters : the growth of "the global village", the great increase in the development of international human rights standards and obligations, the development of libraries and legal information sources, changes in legal education and major differences in the experience of lawyers in private and government practice and on the bench.

Attorney-General [1998] 1 NZLR 513.

51 See A Frame n 28 above, Wharton $v$ Registrar of Patents [1921] NZLR 817 for a relevant Salmond judgment, and more generally "The impact of American ideas on New Zealand's educational policy, practice and theory : the case of law" (1988) 18 VUWLR 327.

52 Melser v Police [1967] NZLR 437, 445. 


\section{The wider legal and political culture}

It is to those great (actual or potential) changes in legal education and professional experience to which I wish to refer finally and briefly, as well as to the role of the University. Those matters are to be seen in the much wider context of the huge, even revolutionary changes in the way the world is organised and operates. ${ }^{53}$ I make two points. The first is about the curriculum. The Institut de Droit International, an organisation of about 150 lawyers in practice, in government, in the academy and in the judiciary, established in 1873, and chosen from all parts of the world last year adopted a resolution on The Teaching of Public and Private International Law. The preamble begins by emphasising practical matters about the work of lawyers and their education.

Emphasising that international law increasingly affects the content of municipal law and that a knowledge of international law is necessary to discharge a wide range of professional responsibilities at the national level and the responsibilities of individuals in an increasingly cohesive international society;

Reaffirming that, in the conditions prevailing in the present world, legal education is incomplete if it does not cover the basic elements of public and private international law;

Noting that the international community is moving to a more complex system in which nonState actors are increasing in importance and that international and national laws are becoming more closely interrelated;

Anxious to ensure that the teaching of international law is sufficiently adapted to changes in the international system and to the role and interests of various non-State actors, including individuals.

It accordingly recommended that:

1 Every school and faculty of law offer a foundation course or courses on public and private international law. The purpose of such courses is to familiarise students with the basic elements of public and private international law and to provide a foundation on which more specialized knowledge can be acquired at later stages of the educational process.

2 No law student graduate from schools or faculties of law or enter the practice of law and the judicial or diplomatic service without having had a foundation course or courses on public and private international law.

53 See eg the papers by Mansbach and the writer in G A Wood and L S Leland Jr (eds) State and Sovereignty : Is the State in Retreat? (1997). 
I would add to that, the critical importance of the early exposure of law students to international law and the international context in which national law operates. It should not be seen as an "add on". It has the fundamental character demonstrated by the fact that Chancellor Kent began his enormously influential Commentaries on American Law (1826) by discussing "Of the Law of Nations". The law of New York or the United States could not be properly understood ahead of and except in that wider context.

My second point is about legal theory, legal method, the legal system or jurisprudence. The label does not matter for my purposes. Those in the universities are in a great position to address both the large questions about the organisation of public and private power and the more precise ones of how the rules are to be written and the relative roles of the various institutions - public and private, national and international and of the processes for the codification, development and application of the law and the handling or resolution of disputes. Those theoretical or jurisprudential questions are truly practical ones as well as being at the heart of the academic enterprise.

I do not deny the value of some particular criticism of law reform proposals, legislation and court decisions - although it is not really helpful to be told with at best limited reasons that in one or other of those contexts I have gone too far or not far enough or simply that I am a "liberal". Somewhat more suggestive of the broader approach which I would welcome, so long as it also carefully rests on relevant detail, is a very recent criticism by a non-lawyer of me and others for engaging in "the coughing and shuffling of feet that comes from embarrassment". ${ }^{54}$

Work on the bigger picture is truly part of the essential role of the academic in the University to advance, maintain and disseminate knowledge by teaching and research and to act as a constructive critic of the international society as well as of the national one. ${ }^{55}$

54 Kenneth Minogue, Waitangi : Morality and Reality (1998) 86.

55 I refer to the terms of the individual and general university statutes eg Victoria University of Wellington Act 1961 s 3(1) and Education Act 1989 s 161(4)(a)(v). 